\title{
Tubal choriocarcinoma presented as ruptured ectopic pregnancy: a case report and review of the literature
}

\author{
Shengjie $\mathrm{Xu}^{\dagger}$, Xiaohong Song ${ }^{\dagger}$, Chengjuan $\mathrm{Jin}^{*}$ and Yanli Li
}

\begin{abstract}
Background: Tubal choriocarcinoma is an extremely rare but highly malignant trophoblastic tumor, which may be either gestational or non-gestational in origin. Due to atypical clinical manifestations and symptoms similar to ectopic pregnancy, it is easily to be confused with ectopic pregnancy. In addition, inadequate understanding of this rare disease by clinicians often leads to misdiagnosis or missed diagnosis, which in turn results in delayed treatment or even tumor metastasis.
\end{abstract}

Case presentation: This report summarized a case of a woman who was finally diagnosed as tubal choriocarcinoma through the follow-up of serum $\beta$ hCG levels and histopathological results after undergoing salpingectomy for being misdiagnosed as ectopic pregnancy. Five courses of adjuvant chemotherapy (5fluorouracil, actinomycin-D, vinorelbine regime) have been administered to the patient in the prevention of any recurrences. During 1-year follow-up, the patient was asymptomatic and presented no evidence of recurrence.

Conclusions: Tubal choriocarcinoma is easily to be confused with ectopic pregnancy. By analyzing this case and previous related cases, we aimed to provide references for clinicians in the diagnosis and treatment of tubal choriocarcinoma.

Keywords: Tubal choriocarcinoma, Ectopic pregnancy, Histopathology, Immunohistochemistry, Chemotherapy

\section{Background}

Tubal choriocarcinoma is a kind of highly malignant trophoblastic tumor, which can be either gestational or non-gestational in origin. According to reports, the incidence of tubal choriocarcinoma is about $1.5 / 10^{6}$ [1]. The age of onset ranges from 16 to 56 years with an average of 33 years. Non-gestational tubal choriocarcinoma is extremely rare, and gestational tubal choriocarcinoma tends to occur on the basis of tubal pregnancy. In few cases, gestational tubal choriocarcinoma occurs after

\footnotetext{
*Correspondence: chengjuanjin@126.com; liecho121@126.com

${ }^{\dagger}$ Shengjie Xu and Xiaohong Song contributed equally to this work. Department of Obstetrics and Gynecology, Shanghai General Hospital, School of Medicine, Shanghai Jiao Tong University, 100\# Haining Rd, Shanghai 200080, China
}

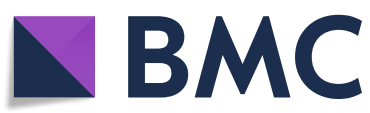

(c) The Author(s). 2020 Open Access This article is licensed under a Creative Commons Attribution 4.0 International License, which permits use, sharing, adaptation, distribution and reproduction in any medium or format, as long as you give appropriate credit to the original author(s) and the source, provide a link to the Creative Commons licence, and indicate if changes were made. The images or other third party material in this article are included in the article's Creative Commons licence, unless indicated otherwise in a credit line to the material. If material is not included in the article's Creative Commons licence and your intended use is not permitted by statutory regulation or exceeds the permitted use, you will need to obtain permission directly from the copyright holder. To view a copy of this licence, visit http://creativecommons.org/licenses/by/4.0/ The Creative Commons Public Domain Dedication waiver (http://creativecommons.org/publicdomain/zero/1.0/) applies to the data made available in this article, unless otherwise stated in a credit line to the data. even simultaneously with an intrauterine pregnancy [2]

Tubal choriocarcinoma can be easily misdiagnosed as ectopic pregnancy due to its main clinical manifestations similar to those of ectopic pregnancy, such as amenorrhea, irregular vaginal bleeding, abdominal pain, and elevated serum $\beta$ hCG. Delayed treatment or even tumor metastasis may be caused if not diagnosed and intervened in time. Therefore, how to make a differential diagnosis and better understand and treat such diseases has attracted more and more attention from obstetricians and gynecologists in recent years. This article summarizes and analyzes the epidemiology, disease characteristics, clinical manifestations, diagnosis, and treatment of tubal choriocarcinoma that is easily 


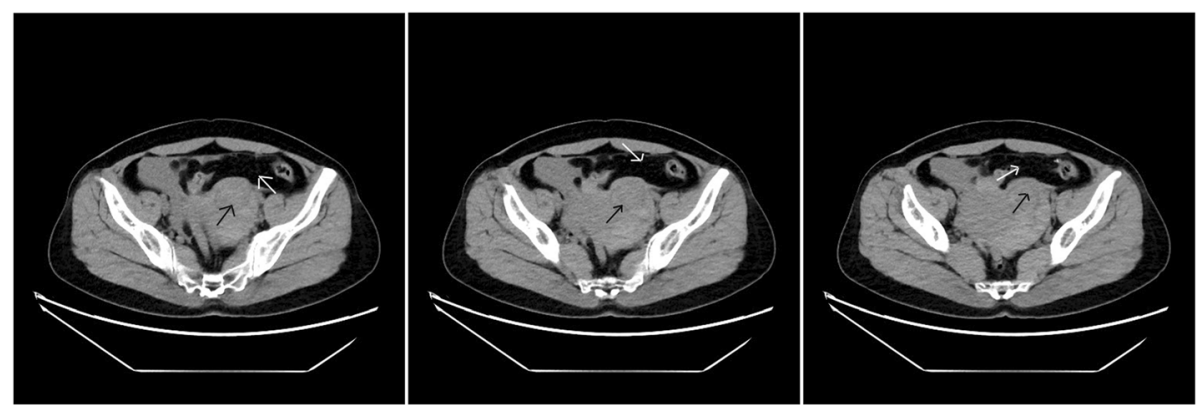

Fig. 1 Preoperative CT scan of the abdomen with arrow mark showing adnexal mass (black) and bloody pelvic effusions (white)

misdiagnosed as ectopic pregnancy, with a view to provide a reference for clinicians.

\section{Case presentation}

A 42-year-old Asian woman (gravida 5, para2) was admitted in the emergency room due to amenorrhea of 37 days, vaginal bleeding for 1 week, and intensive lower abdominal pain for half day. On examination, her vital functions were stable, blood pressure was $104 / 72 \mathrm{mmHg}$, and pulse rate was $83 / \mathrm{min}$. Gynecological examination revealed a small amount of dark blood in the vagina and a sharp bilateral adnexal pain with rebound tenderness.

On laboratory examination, leukocyte count 14,880/ $\mathrm{mm}^{3}$, hemoglobin $10.2 \mathrm{~g} / \mathrm{dl}$, and serum $\beta$ hCG $>10,000$ $\mathrm{mIU} / \mathrm{ml}$ were detected. CT scan revealed the presence of a low-density shadow in the left accessary area and a large amount of bloody effusions in the pelvic cavity (Fig. 1).

A woman of reproductive age (a history of abortion 13 months ago) presented with amenorrhea, vaginal bleeding, lower abdominal pain, and elevated serum $\beta$ hCG level raises the suspicion of ruptured ectopic pregnancy, which always presents with similar features and was considered as the first possibility in this case. Subsequently, approximately $3 \mathrm{ml}$ non-coagulated blood was extracted from the puncture of posterior fornix of vagina. Considering that persistent bleeding may be lifethreatening, a diagnostic laparoscopy was carried out immediately. Upon entering the abdominal cavity, blood clot of approximately $500 \mathrm{ml}$ was seen and subsequently evacuated. The uterus was normal. The right fallopian tube and ovary were normal in appearance. The left ovary was within normal limits but there was a ruptured and actively bleeding ectopic mass of approximately $6 \times$ $5 \mathrm{~cm}$ at the ampulla of left fallopian tube. A left-sided salpingectomy was carried out. Finally, the mass was sent for histopathological examination and the serum $\beta$ HCG levels were monitored continuously during postoperative period (Table 1).

Histopathological examination revealed that cytotrophoblasts and syncytiotrophoblasts were significantly proliferated in the mass, infiltrating the muscle layer of the fallopian tubal wall and the soft tissue of the adventitia, accompanied by extensive hemorrhage and necrosis (Fig. 2). Immunohistochemical analysis was positive for $\beta$ hCG, cytokeratin (CK), p63, p53, and $\alpha$-inhibin and negative for human placental lactogen (HPL), placental alkaline phosphatase (PLAP), PR, ER, PAX8, and WT1, whereas Ki 67 proliferation index was $60 \%$ (Fig. 3). The final diagnosis was tubal choriocarcinoma based on these findings.

Subsequently, a metastatic workup including CT scans of the brain, chest, and abdomen and contrast-enhanced MRI of the pelvis comprehensively ruled out the possibility of systemic metastasis of the tumor. Finally, the patient was categorized into FIGO stage I with WHO prognostic score of at least 10, representing high risk. Details of the prognostic scoring were shown as follows: age-score 1 ( 42 years of age), antecedent pregnancyscore 1 (abortion), interval from index pregnancy-score 4 (patient had an abortion $\geq 13$ months back), pretreatment $\beta$ HCG value-score at least $2(>10,000 \mathrm{mIU} / \mathrm{ml}$, no specific value), largest tumor size-score 2 (approximately $6 \times 5 \mathrm{~cm}$ ), site of metastasis-score 0 (none), number of metastatic lesions-score 0 (none), and previous failed chemotherapy-score 0 (none).

Table 1 Monitoring of the serum $\beta$ hCG levels during perioperative stage

\begin{tabular}{lll}
\hline Date & $\boldsymbol{\beta}$ hCG $(\mathbf{m l U} / \mathbf{m L})$ & Note \\
\hline Pre-operation & $>10,000$ & No exact value \\
Operation day & $>10,000$ & No exact value \\
1st day after operation & 8152 & $/$ \\
2nd day after operation & 5148 & $/$ \\
10th day after operation & 570.9 & $/$ \\
13th day after operation & 217.0 & $/$ \\
14th day after operation & 127.7 & $/$ \\
15th day after operation & 95.78 & FAV \#1 start \\
21st day after operation & 2.1 & FAV \#1 end \\
\hline
\end{tabular}

FAV 5-fluorouracil, actinomycin-D, vinorelbine 

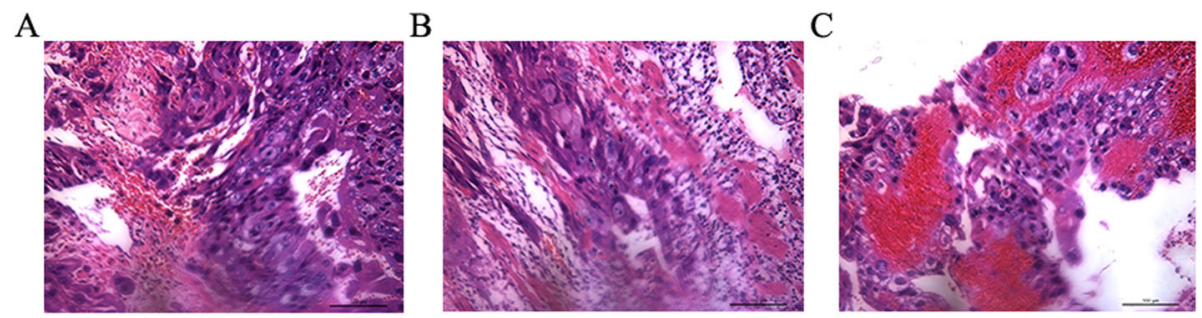

Fig. 2 Histopathologic view of left tubal choriocarcinoma presenting the biphasic feature of mixed cytotrophoblasts and syncytiotrophoblasts (a) infiltrating the muscle layer of the fallopian tubal wall and the soft tissue of the adventitia (b). Extensive hemorrhage was present, as was necrosis (c). Hematoxylin and eosin (H\&E) stain. $\times 200$

The serum $\beta$ hCG level dropped to $95.78 \mathrm{mIU} / \mathrm{ml}$ at 15th day after operation and just before implementing adjuvant chemotherapy (5-fluorouracil, actinomycin-D, vinorelbine (FAV) regime). The normal level of $\beta$ hCG was achieved after the first course of adjuvant chemotherapy (Table 1). Subsequently, four courses of consolidation chemotherapy in total were administered to the patient at intervals of 4 weeks in the prevention of any recurrences. The main adverse reactions during consolidation chemotherapy are bone marrow suppression and gastrointestinal. However, the toxicity and the side effects were tolerable after conventional symptomatic and supportive treatment.
In addition, the patient was advised to avoid pregnancy for 2 years and instructed to take effective contraceptive measures. During 1-year follow-up, the patient was asymptomatic and presented no evidence of recurrence. At present, the patient is still being followed up by performing serum $\beta$ hCG testing and imaging examination at regular intervals.

\section{Review of the literature}

The available literatures of tubal choriocarcinoma presenting as ectopic pregnancy were obtained from MEDL INE and Google Scholar. Two scholars independently screened qualified publications from the database

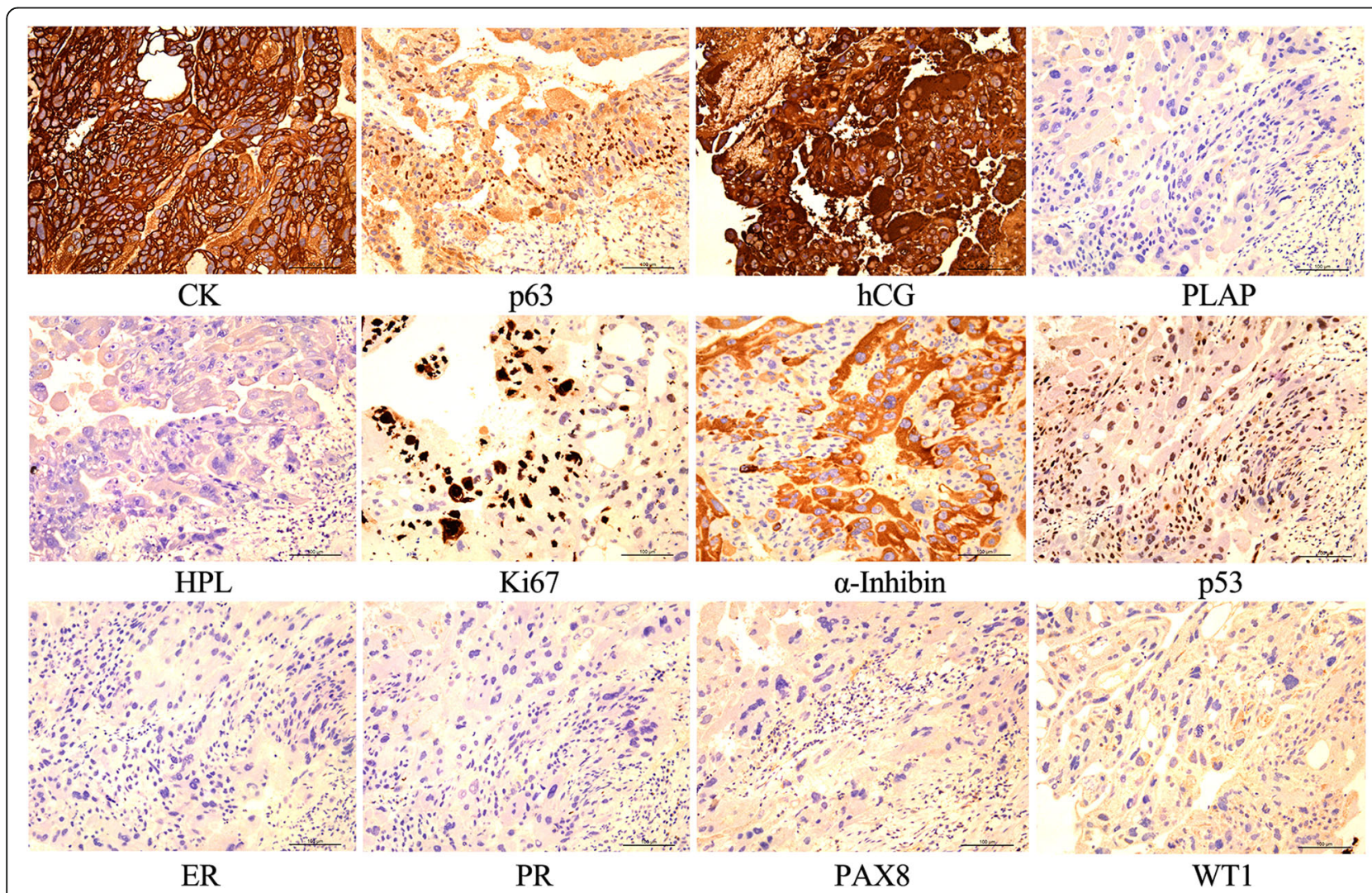

Fig. 3 The application of immunohistochemical markers provided further support for the diagnosis of tubal choriocarcinoma (d). $\times 200$ 
through the content of the title and abstract. A total of 12 cases were extracted from the databases, and the disease characteristics, clinical manifestations, treatment, and outcome of tubal choriocarcinoma were summarized in Table 2.

\section{Discussion}

Tubal choriocarcinoma is a rare but aggressive ectopic choriocarcinoma and may be either gestational or nongestational in origin [14]. Regardless of gestational or non-gestational tubal choriocarcinoma, the common feature is that early metastasis and spread of the cancer are prone to occur, of which lung metastasis ranks the first place, followed by para-uterine metastasis $[9,12]$.

Patients with tubal choriocarcinoma are rare and often have similar clinical symptoms to those of tubal ectopic pregnancy including amenorrhea, vaginal bleeding, pelvic pain, and increased serum $\beta$ hCG $[2,15]$. Therefore, diagnostic errors always occurred. In addition, the respiratory symptoms of advanced tubal choriocarcinoma patients with lung metastasis were often ignored, leading to delayed therapy and disease progression $[9,12]$. Therefore, it is essential to exclude choriocarcinoma when diagnosing ectopic pregnancy, especially when patients are accompanied by respiratory distress, bloody sputum, and other respiratory symptoms.

It is important to distinguish between tubal choriocarcinoma and tubal ectopic pregnancy through dynamic monitoring of serum $\beta$ hCG levels, diagnostic laparoscopy, and histopathological examination. In general, the serum $\beta$ hCG of patients with tubal choriocarcinoma tended to abnormally elevate within a short time after amenorrhea, while that of patients with tubal ectopic pregnancy rarely exceeds $10,000 \mathrm{mIU} / \mathrm{ml}$ [14]. In some cases, the serum hCG levels of patients after surgery were not significantly reduced or even continuously increased. On this occasion, the tubal choriocarcinoma, even very rare, should be kept in mind. Diagnostic laparoscopy has a unique advantage in dealing with lifethreatening intra-abdominal bleeding caused by either

Table 2 Summary of cases of tubal choriocarcinoma

\begin{tabular}{|c|c|c|c|c|c|c|c|}
\hline Author & Age & Clinical presentation & $\begin{array}{l}\beta \text { hCG } \\
(\mathrm{mlU} / \mathrm{ml})\end{array}$ & $\begin{array}{l}\text { Tumor } \\
\text { size }(\mathrm{cm})\end{array}$ & Surgery & Chemotherapy & Outcome \\
\hline Mehrotra et al. [2] & 30 & $\begin{array}{l}\text { Abdominal pain, fever, fatigue, } \\
\text { tachycardia, and palpable mass } 1 \\
\text { month after first trimester abortion }\end{array}$ & 326,100 & $14 \times 16$ & $\begin{array}{l}\text { Left-sided } \\
\text { salpingoophrectomy }\end{array}$ & EMA-CO & $\begin{array}{l}\text { No evidence of } \\
\text { recurrence }\end{array}$ \\
\hline Mundkur et al. [3] & 26 & $\begin{array}{l}\text { Mass abdomen, pain in the lower } \\
\text { abdomen, vomiting, loss of } \\
\text { weight, and loss of appetite }\end{array}$ & 151,545 & $\begin{array}{l}10 \times 10 \times \\
5\end{array}$ & $\begin{array}{l}\text { Right adenexectomy } \\
\text { with partial } \\
\text { infracholicomentectomy }\end{array}$ & EMA-CO & $\begin{array}{l}\text { No evidence of } \\
\text { recurrence }\end{array}$ \\
\hline Rettenmaier et al. [4] & 32 & Abdominal cramping & 4759 & $\begin{array}{l}3.5 \times 1.7 \\
\times 2.8 ; 4.3 \\
\times 1.3 \times \\
4.4\end{array}$ & $\begin{array}{l}\text { Left-sided partial } \\
\text { salpingectomy }\end{array}$ & $\begin{array}{l}\text { Refused } \\
\text { chemotherapy }\end{array}$ & $\begin{array}{l}\text { Refused follow- } \\
\text { up }\end{array}$ \\
\hline Karaman et al. [5] & 31 & $\begin{array}{l}\text { Amenorrhea, left lower abdominal } \\
\text { pain, and fatigue }\end{array}$ & $29,251.4$ & $4 \times 3$ & $\begin{array}{l}\text { Left-sided complete } \\
\text { salpingectomy }\end{array}$ & MTX & $\begin{array}{l}\text { No evidence of } \\
\text { recurrence }\end{array}$ \\
\hline Cianci et al. [6] & 30 & Left lower abdominal pain & 24,474 & 8 & $\begin{array}{l}\text { Left-sided } \\
\text { salpingoophrectomy }\end{array}$ & $\mathrm{EMA}-\mathrm{CO}$ & $\begin{array}{l}\text { No evidence of } \\
\text { recurrence }\end{array}$ \\
\hline Boynukalin et al. [7] & 38 & $\begin{array}{l}\text { Abdominal pain and vaginal } \\
\text { bleeding }\end{array}$ & $>15,000$ & None & $\begin{array}{l}\text { Right-sided } \\
\text { salpingectomy }\end{array}$ & None & None \\
\hline Gálvez et al. [8] & 33 & $\begin{array}{l}\text { Intense pain in the right iliac } \\
\text { cavity and limited genital bleeding }\end{array}$ & 142.1 & 3.73 & $\begin{array}{l}\text { Right-sided } \\
\text { salpingectomy }\end{array}$ & $\begin{array}{l}\text { VCR, ActD, MTX, } \\
\text { LV }\end{array}$ & $\begin{array}{l}\text { No evidence of } \\
\text { recurrence }\end{array}$ \\
\hline Lee et al. [9] & 31 & $\begin{array}{l}\text { Dyspnea and blood-tinged } \\
\text { sputum }\end{array}$ & 228,300 & $7 \times 6 \times 4$ & $\begin{array}{l}\text { Tumorectomy with left } \\
\text { salpingectomy and } \\
\text { infracolic omentectomy }\end{array}$ & EMA-CO & $\begin{array}{l}\text { No evidence of } \\
\text { recurrence }\end{array}$ \\
\hline Butler et al. [10] & 24 & $\begin{array}{l}\text { Vaginal bleeding, lower abdominal } \\
\text { pain, and amenorrhea }\end{array}$ & 15,000 & 2.6 & $\begin{array}{l}\text { Left-sided } \\
\text { salpingectomy }\end{array}$ & MTX & $\begin{array}{l}\text { No evidence of } \\
\text { recurrence }\end{array}$ \\
\hline Lin et al. [11] & 38 & $\begin{array}{l}\text { Pregnancy of unknown location } \\
\text { over } 9 \text { months following ovarian } \\
\text { induction }\end{array}$ & 267,836 & 5 & $\begin{array}{l}\text { Excision of the right } \\
\text { ovarian cyst and the left } \\
\text { uterine tube }\end{array}$ & MTX & $\begin{array}{l}\text { No evidence of } \\
\text { recurrence }\end{array}$ \\
\hline Ibrahim et al. [12] & 34 & $\begin{array}{l}\text { A positive urine test and } \\
\text { respiratory distress }\end{array}$ & 752,601 & None & $\begin{array}{l}\text { Left-sided } \\
\text { salpingectomy and } \\
\text { wedge resection of the } \\
\text { broad ligament }\end{array}$ & None & $\begin{array}{l}\text { Died of lung } \\
\text { metastasis of } \\
\text { tubal } \\
\text { choriocarcinoma }\end{array}$ \\
\hline Nakayama et al. [13] & 26 & $\begin{array}{l}\text { Genital bleeding and a persistently } \\
\text { high level of } \beta \text { hCG }\end{array}$ & 9903 & $6.4 \times 1.4$ & $\begin{array}{l}\text { Right-sided } \\
\text { salpingectomy }\end{array}$ & None & $\begin{array}{l}\text { No evidence of } \\
\text { recurrence }\end{array}$ \\
\hline
\end{tabular}


ruptured ectopic pregnancy or tubal choriocarcinoma. Most importantly, histopathological specimens used for the final diagnosis could be obtained from diagnostic laparoscopy. In addition, it is essential to carefully dissect and inspect the excised lesions during the operation. When no villous structures are visually observed in the excised lesions, it is strongly recommended to execute intraoperative frozen section biopsy for the differential diagnosis between ectopic pregnancy and tubal choriocarcinoma. Histopathology is the golden standard for diagnosing choriocarcinoma. The typical histological characteristics of tubal choriocarcinoma are columns of hypertrophic and poorly differentiated trophoblastic cells without villous structures and the invasion of muscular tissue with extensive hemorrhage and necrosis $[2,6]$.

Adjuvant chemotherapy following salpingectomy is essential and effective for the treatment of tubal choriocarcinoma. Currently, the chemotherapy regimens for tubal choriocarcinoma were selected with reference to the regimens used in the treatment of trophoblastic tumor. In general, patients of low-risk are treated with single-agent chemotherapy, while patients of high-risk are treated with combined chemotherapy. At present, the level of serum $\beta$ hCG is widely used as the main criterion for judging the therapeutic effect of tubal choriocarcinoma. But even when the serum hCG reaches the normal level, consolidation chemotherapy is still recommended in prevention of clinical recurrences [2, 6, 14]. Generally, 1 to 2 courses of consolidation chemotherapy are recommended for low-risk patients and 2 to 4 courses for high-risk patients. Life-long serum $\beta$ hCG monitoring and imaging examination is essential for patients with tubal choriocarcinoma as there is still no clear guideline indicating when to stop monitoring [16].

\section{Conclusion}

When diagnosing ectopic pregnancy, any other disease of tubal origin like tubal choriocarcinoma should be kept in mind for differential diagnosis. Careful examinations of pathologic specimens and postoperative monitoring of $\beta$ hCG titers are emphasized to avoid misdiagnosis of ectopic tubal choriocarcinoma, although it is a rare condition. Apart from complete surgical resection, principles for the management of tubal choriocarcinoma also include postoperative adjuvant chemotherapy, imaging follow-up, and lifetime $\beta$ hCG monitoring in order to avoid any risk of metastasis and recurrences.

\section{Abbreviations}

FAV: 5-Fluorouracil, actinomycin-D, vinorelbine; hCG: Human chorionic gonadotropin; CK: Cytokeratin; HPL: Human placental lactogen; PLAP: Placental alkaline phosphatase; EMA-CO: Etoposide, methotrexate, actinomycin-D, cyclophosphamide, oncovin; MTX: Methotrexate; ActD: Actinomycin-D; LV: Leucovorin; VCR: Vincristine

\section{Acknowledgements}

Not applicable.

\section{Authors' contributions}

S. Xu made substantial contributions to analysis and interpretation of data and was involved in drafting the manuscript and revising it critically for important intellectual content. X Song made substantial contributions to conception, design and acquisition of data. C. Jin and $Y$. Li gave final approval of the version to be published and agreed to be accountable for all aspects of the work. The author(s) read and approved the final manuscript.

\section{Funding}

This work was supported financially by the National Natural Science Foundation of China (Grand No. 81302252) and the Natural Science Foundation of Shanghai (Grand No. 18ZR1430500).

\section{Availability of data and materials}

The datasets used and/or analyzed during the current study are available from the corresponding author on reasonable request.

\section{Ethics approval and consent to participate}

The collection of patient's clinical data was approved by the Ethics Committee of the School of Medicine of Shanghai Jiao Tong University and performed in accordance with the Declaration of Helsinki.

\section{Consent for publication}

Written informed consent was obtained from the patient for publication of this report and accompanying images. A copy of this written consent is available for review by the Editor-in Chief of this journal.

\section{Competing interests}

The authors declare that they have no competing interests.

Received: 8 July 2020 Accepted: 3 September 2020

Published online: 12 September 2020

\section{References}

1. Gillespie AM, Lidbury EA, Tidy JA, Hancock BWJIJoGC. The clinical presentation, treatment, and outcome of patients diagnosed with possible ectopic molar gestation. 2004;14:366-369.

2. Mehrotra S, Singh U, Goel M, Chauhan S. Ectopic tubal choriocarcinoma: a rarity. BMJ Case Rep. 2012;2012:bcr-2012-006318.

3. Mundkur A, Rai L, Hebbar S, Guruvare S, Adiga P. Fallopian tube choriocarcinoma presenting as ovarian tumour: a case report. J Clin Diagn Res. 2015;9:Qd01-2.

4. Rettenmaier MA, Khan HJ, Epstein HD, Nguyen D, Abaid LN, Goldstein BH. Gestational choriocarcinoma in the fallopian tube. J Obstet Gynaecol. 2013; 33:912-4.

5. Karaman E, Çetin O, Kolusari A, Bayram I. Primary tubal choriocarcinoma presented as ruptured ectopic pregnancy. J Clin Diagn Res. 2015;9:Qd17-8.

6. Cianci S, Vitale SG, Tozzi R, Cignini P, Padula F, D'Emidio L, et al. Tubal primary metastatic choriocarcinoma coexistent with a viable early pregnancy: a case report. J Prenat Med. 2014;8:47-9.

7. Boynukalin FK, Erol Z, Aral Al, Boyar IH. Gestational choriocarcinoma arising in a tubal ectopic pregnancy: case report. Eur J Gynaecol Oncol. 2011;32: 592-3.

8. Gálvez CR, Fernández VC, de Los Reyes JM, Jaén MM, Teruel RG. Primary tubal choriocarcinoma. Int J Gynecol Cancer. 2004;14:1040-4.

9. Lee SM, Kang JH, Oh SY, Hong JS, Kim JW. A successfully treated case of primary tubal choriocarcinoma coexistent with viable intrauterine pregnancy. Gynecol Oncol. 2005;97:671-3.

10. Butler R, Chadha Y, Davies J, Singh M. A case of primary tubal gestational choriocarcinoma. Aust N Z J Obstet Gynaecol. 2010;50:200-1.

11. Lin LH, Koji F, Azeka HE, Regina S, Manatta TL, Rosa MFA, et al. Gestational tubal choriocarcinoma presenting as a pregnancy of unknown location following ovarian induction. 2018;2018:1-6.

12. Ibrahim, Zainal, Abidin, Lung, Wong, Siong, et al. Fatal choriocarcinoma syndrome suspected of being an ectopic pregnancy. 2014.

13. Nakayama M, Namba A, Yasuda M, Hara M, Ishihara O, Itakura AJJO, et al. Gestational choriocarcinoma of fallopian tube diagnosed with a combination of p57. 2011;37(4):1493-6. 
14. Nayama M, Lucot JP, Boukerrou M, Collinet P, Cosson M, Vinatier D. Tubal choriocarcinoma: a case report and review of the literature. J Gynecol Obstet Biol Reprod (Paris). 2007;36:83-6.

15. Muto MG, Lage JM, Berkowitz RS, Goldstein DP, Bernstein MR. Gestational trophoblastic disease of the fallopian tube. J Reprod Med. 1991;36:57-60.

16. Lin LH, Fushida K, Hase EA, Schultz R, Tenorio LM, Madia FAR, et al.

Gestational tubal choriocarcinoma presenting as a pregnancy of unknown location following ovarian induction. Case Rep Obstet Gynecol. 2018;2018: 4705192.

\section{Publisher's Note}

Springer Nature remains neutral with regard to jurisdictional claims in published maps and institutional affiliations.

Ready to submit your research? Choose BMC and benefit from:

- fast, convenient online submission

- thorough peer review by experienced researchers in your field

- rapid publication on acceptance

- support for research data, including large and complex data types

- gold Open Access which fosters wider collaboration and increased citations

- maximum visibility for your research: over $100 \mathrm{M}$ website views per year

At $B M C$, research is always in progress.

Learn more biomedcentral.com/submissions 